Design General Accounting System of Mosque Management Institution for Accountability of Mosque Financial Management (Case Study at DKM At-Taqwa KPAD and DKM Luqmanul Hakim POLBAN

\title{
Rancangan Sistem Akuntansi Pokok Lembaga Pengelola Masjid Untuk Akuntabilitas Pengelolaan Keuangan Masjid (Studi Kasus DKM At-Taqwa KPAD dan Luqmanul Hakim POLBAN
}

\author{
Vina Citra Mulyandani ${ }^{1}$, Iyeh Supriatna ${ }^{2}$ \\ Akuntansi, Politeknik Negeri Bandung \\ Email: vina.citra@polban.ac.id
}

\begin{abstract}
The mosque management institution as a public entity needs to hold accountable accounting and financial reporting. Currently, mosque accounting records are still carried out very simply and cannot provide accurate information to record transactions that occur. The existing accounting records are only a recap of cash receipts and payments. The main objective of this research is to determine the proposed main accounting system design that can be applied by the mosque management institution or mosque prosperity council according to PSAK 45. The designs produced in this study are: account classification, financial report format, recording method, and book or note format. accounting. The research was conducted using a case study qualitative research method at DKM At-Taqwa KPAD Gegerkalong and DKM Luqmanul Hakim POLBAN with an accounting information system development approach. Object data about current recording conditions and specifications for accounting recording requirements were collected by interview, observation, and documentation study methods. The results of the analysis of the current system condition data and requirements specifications are used as the basis for selecting alternatives to the proposed general accounting system design.
\end{abstract}

Keywords: design, General Accounting System, accountability

\begin{abstract}
Abstrak
Lembaga pengelola masjid sebagai suatu entitas publik perlu menyelenggarakan akuntansi dan pelaporan keuangan yang akuntabel. Pencatatan akuntansi masjid saat ini masih dilakukan dengan sangat sederhana dan belum bisa menyajikan informasi yang akurat untuk merekam transaksi yang terjadi, catatan akuntansi yang ada hanya berupa rekapan penerimaan dan pengeluaran kas. Penelitian yang dilakukan bertujuan utama untuk menentukan usulan rancangan sistem akuntansi pokok yang dapat diterapkan oleh lembaga pengelola masjid atau dewan kemakmuran masjid sesuai PSAK 45. Rancangan yang dihasilkan dalam penelitian ini berupa: klasifikasi akun, format laporan keuangan, metode pencatatan, dan format buku atau catatan akuntansi. Penelitian dilakukan dengan metode penelitian kualitatif studi kasus pada DKM At-Taqwa KPAD Gegerkalong dan DKM Luqmanul Hakim POLBAN dengan pendekatan pengembangan sistem informasi akuntansi. Data objek tentang kondisi pencatatan saat ini dan spesifikasi kebutuhan pencatatan akuntansi dikumpulkan dengan metode wawancara, observasi, dan studi dokumentasi. Hasil analisis atas data kondisi sistem saat ini dan spesifikasi kebutuhan dijadikan dasar untuk memilih alternatif rancangan sistem akuntansi pokok yang diusulkan.
\end{abstract}

Kata kunci: perancangan, sistem akuntansi pokok, akuntabilitas

\section{PENDAHULUAN}

Masjid merupakan tempat ibadah umat Islam yang Lembaga pengelolanya berupa dewan kemakmuran masjid (DKM) yang sebagiannya telah memiliki badan hukum berupa yayasan. Tugas dari DKM adalah mengelola kegiatan shalat lima waktu berjamaah, penyelenggaraan pendidikan agama non formal melalui kegiatan majlis taklim (pengajian), mengelola penerimaan dan penyaluran zakat, infak dan shadakoh (ZIS).

Sebagai suatu entitas akuntansi, lembaga pengelola masjid merupakan salah satu organisasi sektor publik yang tergolong dalam organisasi nirlaba (non profit oriented). Menurut PSAK 45, suatu entitas nirlaba memiliki karakteristik sumber daya berasal dari pemberi sumber daya yang tidak mengharapkan pembayaran kembali, menghasilkan barang dan/atau jasa tanpa bertujuan memupuk laba, tidak ada kepemilikan seperti umumnya entitas bisnis. Sifat kepemilikan aset masjid, dalam hukum syariat masuk dalam wakaf.

Sebagai suatu organisasi nirlaba yang mengelola sumber daya yang berasal dari masyarakat, 
Lembaga pengelola masjid harus dapat mempertanggung-jawabkan pengelolaan keuangannya karena menyangkut kepentingan orang banyak.

Ada dua alasan yang mendorong lembaga pengelola masjid sebagai entitas akuntansi dan pelaporan, untuk menyajikan informasi keuangan yang memenuhi prinsip akuntabilitas: Pertama, lembaga pengelola masjid mengemban amanah yang kuat untuk mempertanggungjawabkan secara syariat dan juga pertanggungjawaban kepada publik. Kedua, masyarakat pemberi sumber daya (muhsinin, muzakki, atau muwaqqif) sudah menitipkan harta infak, shodaqoh, wakaf-jariyah, dan zakat kepada lembaga masjid berhak mengetahui pengelolaan dana dan sumber daya aset lainnya. Dengan mengetahui pengelolaan dan kondisi sumber daya masjid, masyarakat akan memperoleh kepuasan informasi keuangan masjid yang akan meningkatkan kepercayaan masyarakat kepada lembaga pengelola masjid, sehingga mendorong partisipasi lebih besar.

Kondisi pencatatan keuangan masjid saat ini adalah tidak ada format catatan khusus yang digunakan dalam mencatat pemasukan dan pengeluaran kas yang terjadi. Format laporan keuangannya pun sederhana, terdiri dari kolom nomor, tanggal, keterangan, debit, kredit dan saldo. Menurut pengelola DKM At-Taqwa KPAD Gegerkalong dan DKM Luqmanul Hakim POLBAN untuk memenuhi prinsip akuntabilitas dalam pengelolaan keuangan, mereka masih menghadapi kendala dalam penyelenggaraan pembukuan atau akuntansi, yaitu kurangnya pengetahuan dan keterampilan tentang akuntansi dan prinsip pelaporan keuangan, serta masih kurangnya sumber daya manusia yang bisa melaksanakan kegiatan akuntansi. [3] Untuk memenuhi prinsip akuntabilitas dalam pengelolaan keuangan, masih banyak lembaga pengelola masjid yang masih menghadapi kendala dalam penyelenggaraan pembukuan atau akuntansi, yaitu kurangnya pengetahuan dan keterampilan tentang akuntansi dan prinsip pelaporan keuangan, serta masih kurangnya sumber daya manusia yang bisa melaksanakan kegiatan akuntansi.Hasil penelitian [2] menunjukkan bahwa laporan keuangan yang telah disusun oleh masjid XYZ belum sesuai dengan PSAK Nomor 45 dan masih dalam bentuk buku kas sederhana. Peneliti lain [3] mengungkapkan bahwa laporan keuangan masjid Roudhotul Muchlisin masih dalam bentuk sederhana dan perlakuan pendapatan dan pengeluaran belum sesuai dengan PSAK No. 45 dan sumber daya di bidang akuntansi masih kurang dan akun pada laporan keuangan juga tidak sesuai dengan PSAK No.45.

Laporan keuangan sebagai informasi akuntansi utama dihasilkan melalui suatu sistem akuntansi pokok. Sistem akuntansi pokok merupakan organisasi formulir, catatan, dan laporan keuangan yang dikoordinasi sedemikian rupa untuk menyediakan informasi kuantitatif, terutama yang bersifat keuangan [4].

Penelitian ini berfokus merancang sistem akuntansi pokok lembaga pengelola masjid yang untuk akuntabilitas pengelolaan keuangan masjid. Berdasarkan penelitian terdahulu yang bertema akuntansi masjid lebih menyoroti tentang penerapan PSAK 45 di lembaga masjid. Penelitian yang menghasilkan usulan model atau rancangan sistem akuntansi pokok untuk lembaga pengelolaan masjid, belum ada. Maka rumusan permasalahan dalam penelitian ini adalah bagaimana rancangan sistem akuntansi pokok Lembaga Masjid untuk melakukan proses akuntansi dalam menghasilkan laporan keuangan untuk memenuhi unsur akuntabel sesuai dengan PSAK 45 dan tujuan utama penelitian ini adalah untuk menghasilkan usulan model atau rancangan sistem akuntansi pokok untuk lembaga pengelolaan masjid yang memenuhi asas akuntabilitas yang dapat diterapkan di DKM.

\section{TINJAUAN PUSTAKA}

Beberapa artikel yang penulis kaji, penelitian terdahulu yang bertema akuntansi lembaga pengelolaan masjid lebih menyoroti penerapan PSAK 45 di lembaga masjid. Penelitian yang menghasilkan usulan model atau rancangan sistem akuntansi pokok untuk lembaga pengelolaan masjid, masih belum ada.[5] Adanya tuntutan akuntabilitas pada sektor publik serta pentingnya laporan keuangan yang disusun oleh organisasi nirlaba, maka pembahasan mengenai rancangan akuntansi pokok mengacu PSAK No. 45 perlu dianalisis secara lebih mendalam lagi. Oleh karena itu, yang menjadi perbedaan penelitian ini dengan penelitian lain adalah penelitian ini akan menghasilkan usulan model atau rancangan sistem akuntansi pokok untuk lembaga pengelolaan masjid yang memenuhi asas akuntabilitas yang dapat diterapkan di

DKM. Rancangan berupa: klasifikasi akun, format laporan keuangan, metode pencatatan, dan format catatan akuntansi. Sejalan dengan roadmap penelitian yang sudah dirancang maka model ini akan berkelanjutan sampai menjadi suatu sistem terkomputerisasi yang mendukung akuntabilitas lembaga 
masjid. Berikut referensi primer yang relevan dan dapat mendukung penelitian ini :

\section{A. Organisasi Nirlaba}

Lembaga pegelolaan masjid termasuk organisasi nirlaba sektor publik non pemerintah.Organisasi nirlaba menggunakan basis akuntansi akrual untuk mengakui pendapatan dan bebannya mengacu PSAK 45. Organisasi nirlaba umumnya memperoleh sumber daya dari sumbangan para anggota dan donatur yang tidak mengharapkan adanya pengembalian atas donasi yang mereka berikan[5]. Organisasi nirlaba harus menyusun laporan keuangan untuk mempertanggungjawabkan dana yang diberikan oleh donatur. Apabila organisasi nirlaba memperoleh laba, maka laba tersebut akan dikontribusikan untuk pemenuhan kepentingan publik. Agar mempermudah organisasi nirlaba dalam penyusunan laporan keuangan, maka dibutuhkan suatu sistem akuntansi untuk mengatur penyusunan laporan keuangan[6].

B. Sistem Akuntansi Pokok

Sistem akuntansi pokok merupakan organisasi formulir, catatan, dan laporan keuangan yang dikoordinasi untuk menyediakan informasi kuantitatif, terutama yang bersifat keuangan. Sistem akuntansi pokok merupakan sistem akuntansi utama untuk menghasilkan laporan keuangan. Istilah yang digunakan untuk sistem akuntansi pokok adalah accounting system proper yang mencakup klasifikasi akun (chart of accounts), laporan keuangan, buku besar, jurnal, dan bukti transaksi[8].

C. Metode dan Bentuk Pembukuan

Merancang metode dan bentuk pembukuan adalah merancang sebagian komponen sistem informasi akuntansi. Beberapa hal yang harus dipertimbangkan untuk merancang system informasi akuntansi yang cocok, antara lain: metode pencatatan cash basis dan accrual basis, sistem pencatatan tunggal (single entry) dan sistem pencatatan ganda (double entry). Akuntansi berbasis kas (cash basis), adalah pelaporan pendapatan dan pengeluaran perusahaan pada saat benar-benar diterima atau dibayar. Akuntansi akrual (accrual basis), yaitu pengakuan pendapatan dan pengeluaran pada saat diperoleh atau terjadi.[9].

Dalam single entry system, tidak ada seperangkat aturan yang harus diikuti, bahkan buku-buku akun yang harus diselenggarakan tidak tentu. Single entry systems merujuk pada sistem pembukuan secara manual yang hanya menggunakan akun pendapatan dan biaya. Sistem ini tepat diterapkan pada entitas yang masih kecil dan sangat sederhana. Ketika suatu entitas menjadi lebih kompleks, akan menjadi perlu untuk mengganti ke akuntansi double entry (terlebih lagi melalui penggunaan perangkat lunak).

D. Akuntabilitas

Akuntabilitas menunjukkan hubungan dua pihak yang mana satu pihak (perorangan, kelompok, perusahaan, pemerintah, organisasi, dan sebagainya) secara langsung atau tidak langsung bertanggung jawab kepada pihak lain tentang sesuatu, seperti tindakan, proses, luaran, atau hasil[10]. [7]Akuntabilitas adalah sebuah kewajiban melaporkan dan bertanggung jawab atas keberhasilan atau pun kegagalan pelaksanaan misi organisasi dalam mencapai hasil yang telah ditetapkan sebelumnya, melalui media pertanggungjawaban yang dikerjakan secara berkala. Laporan keuangan yang dapat dipertanggungjawabkan dihasilkan dari sistem akuntansi yang meninggalkan jejak audit (audit trail) sehingga memiliki sifat dapat diaudit dan dapat ditelusuri. Catatan-catatan akuntansi memberikan jejak audit (audit trail) untuk penelusuran transaksi dari dokumen sampai laporan keuangan[11]

\section{METODE}

Tahap awal penelitian ini adalah tahap survey pendahuluan yang merupakan suatu kegiatan identifikasi dalam menggali permasalahan dalam suatu objek dan kondisi tertentu dengan cara melakukan wawancara awal untuk menentukan topik,rumusan permasalahan dan tujuan penelitian. Setelah dilakukan identifikasi maka topik dalam penelitian ini adalah mengenai akuntansi Pokok Lembaga Pengelola Masjid Untuk Akuntabilitas Pengelolaan Keuangan Masjid.

Kemudian dilakukan studi literatur dengan mengumpulkan jurnal dan buku teori terkait. Teknik pengumpulan data yang digunakan adalah wawancara, observasi, dan studi dokumentasi. Jenis data yang akan dideskripsikan dalam penelitian ini adalah berupa narasi dan uraian atau penjelasan data yang diperoleh secara lisan dari narasumber, maupun dari observasi dan studi dokumentasi. Dalam penelitian ini, instrumen penelitian yang utama adalah peneliti sendiri. Agar fokus penelitian menjadi jelas, maka dikembangkan instrumen penelitian berupa pedoman wawancara, observasi dan dokumentasi. 
Sumber data dalam penelitian ini adalah narasumber dari pengurus lembaga pengelola masjid (Dewan Kemakmuran Masjid), terutama ketua, pelaksana pembukuan dan pengurus lain yang relevan dari lembaga pengelola masjid yang menjadi model, serta peneliti sebagai instrumen utama. Data lainnya yang akan diperoleh adalah berupa bukti transaksi penerimaan dan pengeluaran kas, catatan hutang,piutang,dan catatan keuangan lainnya yang kemudian dikelompokan berdasarkan jenis akun transaksi.

Teknik analisis data yang digunakan dalam penelitian ini adalah analisis data kualitatif yang bersifat deskriptif naratif. [13]Teknik ini mengikuti tahapan yang meliputi reduksi data (data reduction), pada tahap ini dilakukan pemilahan dan pengelompokan dokumen transaksi keuangan yang dilakukan pada masjid. Pengelompokan berdasar akun dan diatur dari transaksi pendapatan dan pengeluaran keuangan yang memiliki frekuensi tinggi. Penyajian data (data display), pada tahap ini dilakukan analisis data dengan membuat jurnal,buku besar dan buku besar pembantu serta catatan lainnya dari akun akun yang mendukung transaksi. Pada tahap ini dihasilkan usulan rancangan sistem secara konseptual di atas kertas sebelum implementasi. Penarikan kesimpulan (conclusion drawing), pada tahap ini dilakukan keputusan penentuan model sistem yang akan diimplementasikan. Metode dan bentuk pembukuan akuntansi dan rancangan yang dihasilkan dalam penelitian ini berupa: klasifikasi akun, format laporan keuangan, metode pencatatan, dan format buku atau catatan akuntansi.

Langkah-langkah analisis data sebagai berikut:

1. Periode Pengumpulan Pengumpulan data dalam penelitian ini dilakukan dengan cara mencatat hasil wawancara, observasi, dan dokumentasi.

2. Reduksi Data (Reduction Data) Reduksi data yaitu suatu proses pemilihan, pemutusan perhatian pada

penyederhanaan, pengabstrakan, dan transformasi data "kasar" yang muncul dari catatan-catatan tertulis di lapangan. Reduksi data perlu dilakukan dengancara merangkum dan memilah data yang menjadi fokus penelitian, sehingga data yang tereduksi dapat memberikan gambaran yang jelas dan mempermudah untuk melanjutkan pengumpulan data. Data yang dihasilkan lebih terarah dengan data yang valid dan reliabel. Setelah melakukan observasi dan wawancara, peneliti akan memilih data-data penting dan memfokuskan pada aktivitas keuangan masjid.

3. Penyajian Data (Data Display) Penyajian data dalam kualitatif dapat dilakukan dengan cara menguraikan teks naratif, bagan, hubungan antar kategori, flowchart, template, dan sejenisnya. Penyajian data ini akan memudahkan peneliti memahami apa yang terjadi dan merencanakan kerja selanjutnya.

4. Kesimpulan/Verifikasi (Conclusion Drawing/Verification) Kesimpulan awal yang ditemukan masih bersifat sementara dan dapat berubah apabila tidak dilengkapi bukti yang valid dan konsisten. Akan tetapi jika didukung bukti valid dan konsisten, kesimpulan yang ditemukan merupakan kesimpulan yang kredibel. Data yang sudah diolah kemudian menjadi dasar untuk penyusunan sistem akuntansi pokok masjid dengan menggunakan pedoman akuntansi masjid. Adapun sistem akuntansi pokok yang akan dibuat adalah:

1. Formulir penerimaan dan pengeluaran kas

2. Bagan Perkiraan

3. Jurnal Umum dan Jurnal Khusus

4. Buku Besar dan Buku Pembantu

5. Laporan Keuangan yang terdiri dari :

a. Laporan posisi keuangan

b. Laporan aktivitas

c. Laporan arus kas

d. Catatan atas laporan keuangan

Dalam penelitian kualitatif, maka uji keabsahan data adalah sebagai berikut:

1. Uji Kredibilitas (Validitas Internal)

Uji kredibilitas data atas hasil penelitian kualitatif dapat dilakukan dengan cara sebagai berikut:

a. Perpanjangan pengamatan Peneliti kembali ke lapangan, melakukan pengamatan dengan sumber data yang pernah ditemui untuk membentuk hubungan peneliti dengna narasumber agar memiliki hubungan yang baik, terbuka, dan saling mempercayai. Peneliti melakukan perpanjangan pengamatan selama 1 minggu untuk memastikan data yang diberikan sudah relevan 
dengan keadaan Masjid Lukmanul Hakim dan DKM At-Taqwa.

b. Meningkatkan Ketekunan Peneliti melakukan pengamatan secara lebih cermat dan berkesinambungan. Dengan demikian, kepastian data dan urutan peristiwa akan dapat direkam secara pasti dan sistematis. Setelah memperpanjang pengamatan, peneliti meningkatkan ketekunan untuk memastikan bahwa data yang diperoleh sesuai.

c. Menggunakan Bahan Referensi Peneliti menggunakan bahan referensi sebagai pendukung untuk membuktikan data yang telah ditemukan. Adapun referensi tambahan yang digunakan adalah bukti autentik berupa rekaman wawancara dan juga fotofoto.

2. Pengujian Transferability (Validitas Eksternal)

Pengujian ini adalah teknik untuk menguji validitas eksternal didalam penelitian kualitatif. Untuk menerapkan uji transfelabilitas ini maka peneliti akan memberikan uraian yang rinci, jelas, dan juga sistematis agar penelitian ini dapat mudah dipahami oleh orang lain dan penelitiannya dapat diterapkan oleh masjid lainnya

\section{HASIL PENELITIAN}

Masjid Lukmanul Hakim dan DKM At-Taqwa merupakan organisasi nirlaba yang kegiatan utamanya adalah melakukan kegiatan peribadatan meliputi sholat jumat,sholat lima waktu,qurban,zakat. Dalam hal pendanaannya Masjid Lukmanul Hakim dan DKM At-Taqwa menggunakan dana sumbangan dari donatur sebagai sumber pendanaan utamanya. Oleh karena itu, sudah sewajarnya Masjid Lukmanul Hakim dan DKM At-Taqwa menyusun laporan keuangan sebagai sumber informasi keuangan yang berguna untuk kepentingan masjid. Laporan keuangan ini juga sebagai bentuk pertanggungjawaban atas pengelolaan dana yang masuk dari para donator.

\section{Analisis Kondisi Masjid Lukmanul Hakim dan DKM At-Taqwa}

Dalam penyajian laporan keuanganya, Masjid Lukmanul Hakim dan DKM At-Taqwa belum menerapkan sistem akuntansi pokok yang sesuai dengan PSAK 45. Saat ini Masjid Lukmanul Hakim dan DKM At-Taqwa membuat laporan keuangan berupa catatan pemasukan dan pengeluaran kas setiap minggunya. Penerimaan tersebut terdiri dari:

a. Sumbangan dana dari pihak lain berupa zakat, infaq, shadaqoh, dan wakaf Sedangkan pengeluaran yang dilakukan oleh Masjid Lukmanul Hakim dan DKM At-Taqwa adalah pengeluaran untuk keperluan operasional, seperti pemeliharaan bangunan,sarana dan prasarana, insentif penceramah dan juga biaya lain yang mendukung aktivitas operasional masjid.

b. Berdasarkan hasil wawancara dengan Bendahara Masjid Lukmanul Hakim dan DKM At-Taqwa, diketahui bahwa penyusunan laporan keuangan yang ada hanyalah pencatatan pemasukan dan pengeluaran kas saja.

c. Pencatatan kas yang dilakukan Masjid Lukmanul Hakim dan DKM At-Taqwa menggunakan sistem pencatatan single entry dimana hanya dilakukan pencatatan satu kali. Transaksi yang mengakibatkan kas bertambah akan dicatat pada sisi penerimaan atau sisi debit dan transaksi yang mengurangi kas akan dicatat pada sisi pengeluaran atau kredit. Dari penjelasan di atas dapat diketahui bahwa laporan keuangan yang disusun sangatlah sederhana dan belum bisa dikatakan laporan keuangan. Sistem pencatatan seperti ini juga memang sederhana, akan tetapi banyak kelemahan yang dimilikinya, seperti informasi yang diketahui hanya informasi yang berkaitan dengan kas saja. Berdasarkan hasil wawancara dan observasi, kendala yang dihadapi adalah kurangnya sumberdaya manusia yang paham mengenai akuntansi. Selain itu sulitnya menerapkan standar operasional prosedur keuangan yang ada di Masjid Lukmanul Hakim dan DKM At-Taqwa juga menjadi kendala. Kemudian pengelolaan yang masih kultural juga sangat berpengaruh sehingga menimbulkan kekakuan. Berdasarkan kendala tersebut, sistem akuntansi pokok berdasarkan PSAK 45 sangat dibutuhkan agar membantu bagian keuangan ataupun bendahara di Masjid Lukmanul Hakim dan DKM At-Taqwa untuk melaporkan keuangan yang ada.

Untuk menghasilkan laporan keuangan yang baik tentunya tidak terlepas dari sistem akuntansi pokok dan juga tahapan-tahapan yang harus dilalui, tahapan tersebut menggunakan pendekatan siklus akuntansi yang berupa pengidentifikasian, pencatatan, penggolongan, pengikhtisaran dan pelaporan. Berdasarkan hasil pengamatan yang peneliti lakukan, dalam proses penyusunan 
laporan keuangan Masjid Lukmanul Hakim dan DKM At-Taqwasudah memiliki formulir untuk merekam transaksi yang terjadi, namun Masjid Lukmanul Hakim dan DKM At-Taqwa belum sepenuhnya sesuai dengan sistem akuntansi pokok dan juga siklus akuntansi. Masih banyak tahapan-tahapan yang terlewat. Dalam pelaksanaannya, hanya terdapat tahap pengidentifikasian. Tahap pencatatan yang dilakukan pun belum sesuai karena masih melakukan pencatatan single entry bukan pencatatan jurnal. Sehingga masih banyak komponen-komponen sistem akuntansi yang belum ada. Kelemahan sistem akuntansi pokok yang ada pada Masjid Lukmanul Hakim dan DKM At-Taqwa adalah sebagai berikut:

1. Formulir yang digunakan tidak relevan dan belum dipisah antara pemasukan dan pengeluaran kas

2. Dalam pengisian formulir tidak lengkap

3. Tidak ada bagan akun yang memudahkan dalam pencatatan

4. Bendahara belum melakukan inventarisasi perlengkapan maupun peralatan

5. Tidak ada jurnal khusus maupun jurnal umum

6. Tidak ada buku besar dan buku besar pembantu

7. Belum adanya laporan keuangan yang sesuai dengan PSAK 45

Berdasarkan pemaparan tersebut maka diketahui bahwa Masjid Lukmanul Hakim dan DKM AtTaqwa belum memiliki sistem akuntansi pokok yang sempurna dan sistem akuntansi yang sekarang memiliki banyak kelemahan.

Sebelum mengembangkan sistem akuntansi pokok dilakukan evaluasi terhadap sistem akuntansi yang sekarang diterapkan di Masjid Lukmanul Hakim dan DKM At-Taqwa. Evaluasi ini untuk mengetahui kelemahan-kelemahan yang ada pada sistem akuntansi yang diterapkan sehingga penulis dapat mengembangkan sesuai kebutuhan yang diperlukan oleh Masjid Lukmanul Hakim dan DKM AtTaqwa.

\section{Evaluasi Sistem Akuntansi yang Diterapkan}

Berdasarkan kondisi tersebut, informasi yang dihasilkan untuk donator sebagai bentuk akuntabilitas pengelolaan masjid masih sangat kurang. Maka dibuat alur proses akuntansi masjid sesuai PSAK 45 sebagai berikut :

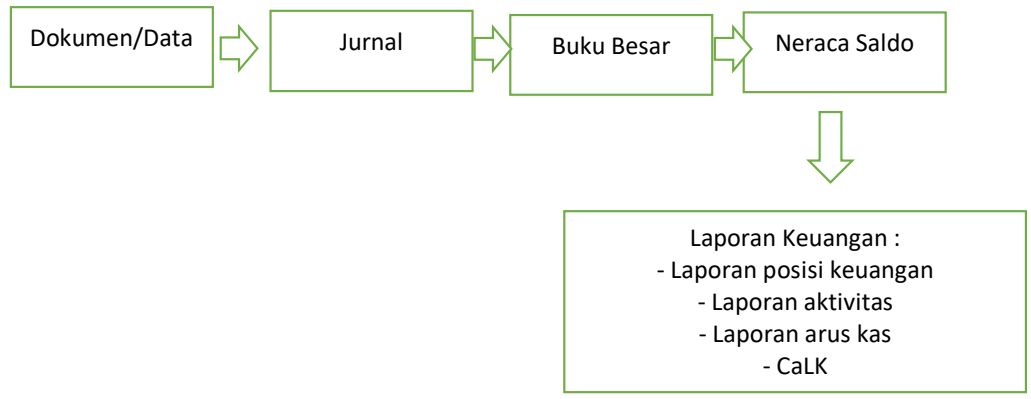

Gambar 1. Alur proses akuntansi masjid

Data yang Dibutuhkan dalam pencatatan akuntansi tersebut adalah Dokumen Transaksi, Jurnal Umum (General Journal), Jurnal Khusus (Special Journal), Buku Besar (Ledger), Apabila diperlukan dilengkapi dengan Buku Besar Pembantu (Subsidiary Ledger), Neraca Saldo (Trial Balance), Laporan Keuangan (Financial Statement), Terdiri dari: Laporan posisi keuangan, Laporan Aktivitas, Laporan arus kas, dan CaLK, Buku Penerimaan, Buku Pembelian, Buku Kas, Buku Bank dan Rekening Koran, Daftar Aset Tetap, Penyusutan dan Amortisasi.

Dokumen Transaksi yang dibutuhkan adalah Bukti atas transaksi yang telah dilakukan dan bukti transaksi yang berhubungan dengan Pihak ke-3, adalah yang diterbitkan oleh Pihak ke-3 seperti Nota, Bon, Kuitansi, Faktur, dll.

\section{Pengembangan Sistem Akuntansi Pokok}

Sistem akuntansi pokok yang memiliki banyak kelemahan tentunya akan menghambat dan berpengaruh terhadap akuntansi di Masjid Lukmanul Hakim dan DKM At-Taqwa. Sehingga pengembangan sistem akuntansi pokok sangat diperlukan. Dengan demikian untuk membuat penyusunan sistem akuntansi pokok berdasarkan PSAK 45, penulis melakukan beberapa tahapan sebagai berikut :

a. Melakukan identifikasi transaksi yang terjadi pada Masjid Lukmanul Hakim dan DKM At- 
Taqwa

b. Mendeskripsikan catatan keuangan dan administrasi yang dimiliki oleh Masjid Lukmanul Hakim dan DKM At-Taqwa

c. Mempelajari sistem pencatatan keuangan di Masjid Lukmanul Hakim dan DKM At-Taqwa

d. Membuat formulir penerimaan dan pengeluaran kas

e. Menyusun kode rekening dan daftar akun

f. Menyusun format neraca saldo awal

g. Memasukan data keuangan ke dalam siklus akuntansi

h. Meninjau kesesuaian laporan keuangan dengan PSAK 45 Berdasarkan hasil wawancara, observasi, dan dokumentasi keuangan maka diperoleh data-data yang menjadi dasar untuk menyusun dan mengembangkan sistem akuntansi pokok pada masjid. Dengan menggunakan pendekatan siklus akuntansi, berikut merupakan penjelasan dari penyusunan sistem akuntansi pokok Masjid Lukmanul Hakim dan DKM At-Taqwa:

\section{PEMBAHASAN}

1. Rancangan Klasifikasi Kode dan Nama Akun yang di sarankan

Rancangan klasifikasi kode dan nama akun bertujuan untuk mempermudah proses pencatatan dan pencarian setiap akun yang ada pada Masjid. Klasifikasi kode dan nama akun yang disarankan oleh penulis yang disesuaikan dengan kebutuhan transaksi pada Masjid.

Tabel 1. Daftar Kode Akun

\begin{tabular}{|l|l|l|l|}
\hline & Aktiva & & $\begin{array}{l}\text { AKTIVA BERMANEN } \\
\text { PERSIH TERIKAT }\end{array}$ \\
\hline 1111 & Kktiva Lancar & 3301 & ABT Permanen-Wakaf \\
\hline 1121 & Rekening Bank & 3309 & ABT Permanen Lainnya \\
\hline 1131 & Beban Dibayar Dimuka & & Perkiraan Laba Rugi \\
\hline 1141 & Piutang & 4101 & Penerimaan-Infaq Jumat \\
\hline 1151 & Aset Lancar Lainnya & 4102 & Penerimaan-Infaq Jemaah \\
\hline & Aktiva Tetap & 4103 & Penerimaan-Sadaqah \\
\hline 1201 & Tanah & 4104 & Penerimaan-Zakat \\
\hline 1202 & Bangunan & 4105 & Penerimaan-Wakaf \\
\hline 1203 & Akumulasi Penyusutan Bangunan & 4106 & Penerimaan Lainnya \\
\hline 1204 & Peralatan Elektronic dan AC & & BEBAN INSENTIF DAN HONOR \\
\hline 1205 & $\begin{array}{l}\text { Akumulasi Penyusutan } \text { Peralatan } \\
\text { Elektronik }\end{array}$ & 5101 & Insentif Takmir dan Petugas Keamanan \\
\hline 1206 & Peralatan Ibadah & 5102 & Insentif Guru Ngaji \\
\hline 1207 & $\begin{array}{l}\text { Akumulasi Penyusutan Peralatan } \\
\text { Ibadah }\end{array}$ & 5103 & Insentif Imam/Khatib Jumat \\
\hline 1208 & Komputer, Printer, \& Scaner & 5104 & Insentif Ustadz/Penceramah \\
\hline 1209 & Akumulasi Penyusutan Komputer & 5109 & Insentif dan Honor Lainnya \\
\hline 1210 & Peralatan Dapur & 5113 & Biaya Peny. Peralatan Kantor \\
\hline 1219 & Akumulasi Penyusutan Peralatan Dapur & 5114 & Biaya Asuransi \\
\hline & Kewajiban & 5201 & Listrik, Air, dan Tetepon \\
\hline & Kewajiban Jangka Pendek & \\
\hline
\end{tabular}


ProBank : Jurnal Ekonomi Dan Perbankan

ISSN : 2579-5597 (online)

Vol 1, No 1 (2021) ; p.14-33;-http://e-journal.stie-aub.ac.id/index.php/probank ISSN : 2252-7885 (cetak)

\begin{tabular}{|l|l|l|l|}
\hline 2101 & Beban yang Masih Harus Dibayar & 5202 & Beban Kebersihan \\
\hline 2102 & Kas Bon kepada Pengurus DKM & 5203 & Perawatan dan Pemeliharaan Ringan \\
\hline 2109 & Utang Lainnya & 5204 & Beban ATK \\
\hline & Kewajiban Jangka Panjang & 5205 & $\begin{array}{l}\text { Langganan Koran, Majalah, Buletin } \\
\text { Jum'at }\end{array}$ \\
\hline 2211 & Utang Bank & 5206 & Jamuan dan Makanan \\
\hline 3101 & AKTIVA BERSIH TIDAK TERIKAT & 5207 & Beban Penyusutan Aset Tetap \\
\hline 3102 & ABTT-Sadaqah & 5219 & Beban Lainnya \\
\hline 3109 & ABTT Lainnya & & \\
\hline & $\begin{array}{l}\text { AKTIVA BERSIH TERIKAT } \\
\text { TEMPORER }\end{array}$ & & \\
\hline 3201 & ABT Temporer-Zakat & & \\
\hline 3209 & ABT Temporer Lainnya & & \\
\hline
\end{tabular}

\section{Penerapan PSAK No.45 dalam Penyajian Laporan Keuangan pada Masjid}

Formulir merupakan dokumen yang sangat penting dalam sistem akuntansi pokok, karena formulir ini akan dijadikan sebagai dasar dalam pencatatan. Sehingga, sebaiknya dalam sistem akuntansi pokok membuat suatu formulir haruslah diutamakan. Dalam pelaksanaannya, Masjid Lukmanul Hakim dan DKM At-Taqwa belum memiliki formulir tersendiri. Berikut rekomendasi format laporan keuangan yang sudah disesuaikan dengan kondisi yang ada pada Masjid Lukmanul Hakim dan DKM At-Taqwa:

\section{a. Neraca Saldo Awal}

Untuk dapat disajikannya laporan keuangan, dalam menerapkan PSAK No.45 maka perlu membuat neraca saldo awal. Sebelum membuat neraca saldo awal tahun maka dilakukan dahulu pendataan aset tetap. Aset yang dimiliki Masjid berupa bangunan masjid, ruang serba guna dan perlengkapan kantor yang diperoleh dari pembelian dan hibah. Berikut format tabel pencatatan aset tetap pada masjid yang dicatat pada kartu inventaris.

Tabel 2. Kartu inventaris

Aset Tetap Bangunan Masjid

Per 31 Desember 20XX

Dalam Rupiah (Rp)

\begin{tabular}{|l|l|l|l|l|l|l|l|l|}
\hline $\begin{array}{l}\text { Nama } \\
\text { Aset }\end{array}$ & $\begin{array}{l}\text { Tahun } \\
\text { Perolehan }\end{array}$ & $\begin{array}{l}\text { Harga } \\
\text { Perolehan }\end{array}$ & $\begin{array}{l}\text { Jlh } \\
\text { Unit }\end{array}$ & Ket. & $\begin{array}{l}\text { Umur } \\
\text { Ekonomis } \\
\text { (Tahun) }\end{array}$ & $\begin{array}{l}\text { Penyusutan } \\
\text { per tahun }\end{array}$ & $\begin{array}{l}\text { Penyusutan } \\
\text { per bulan }\end{array}$ & $\begin{array}{l}\text { Akumulasi } \\
\text { Penyusutan } \\
\text { sampai } \\
\text { bulan } \\
\text { Desember } \\
\text { 20XX }\end{array}$ \\
\hline 1 & 2 & 3 & 4 & 5 & 6 & 7 & 8 & 9 \\
\hline- & - & - & - & - & - & - & - & - \\
\hline
\end{tabular}

Setelah itu dibuat neraca saldo tahun awal tahun. Berikut format Tabel Neraca Saldo Awal Tahun sebelumnya pada Masjid.

Tabel 3.

Neraca Saldo Tahun Sebelumnya

Per 31 Desember 20XX

Dalam Rupiah (Rp)

\begin{tabular}{|l|l|l|l|}
\hline $\begin{array}{l}\text { Kode } \\
\text { akun }\end{array}$ & Nama akun & \multicolumn{2}{|l|}{ Saldo } \\
\cline { 3 - 4 } & Debit & Kredit \\
\hline
\end{tabular}


ProBank : Jurnal Ekonomi Dan Perbankan

ISSN : 2579-5597 (online)

Vol 1, No 1 (2021) ; p.14-33;-http://e-journal.stie-aub.ac.id/index.php/probank ISSN : 2252-7885 (cetak)

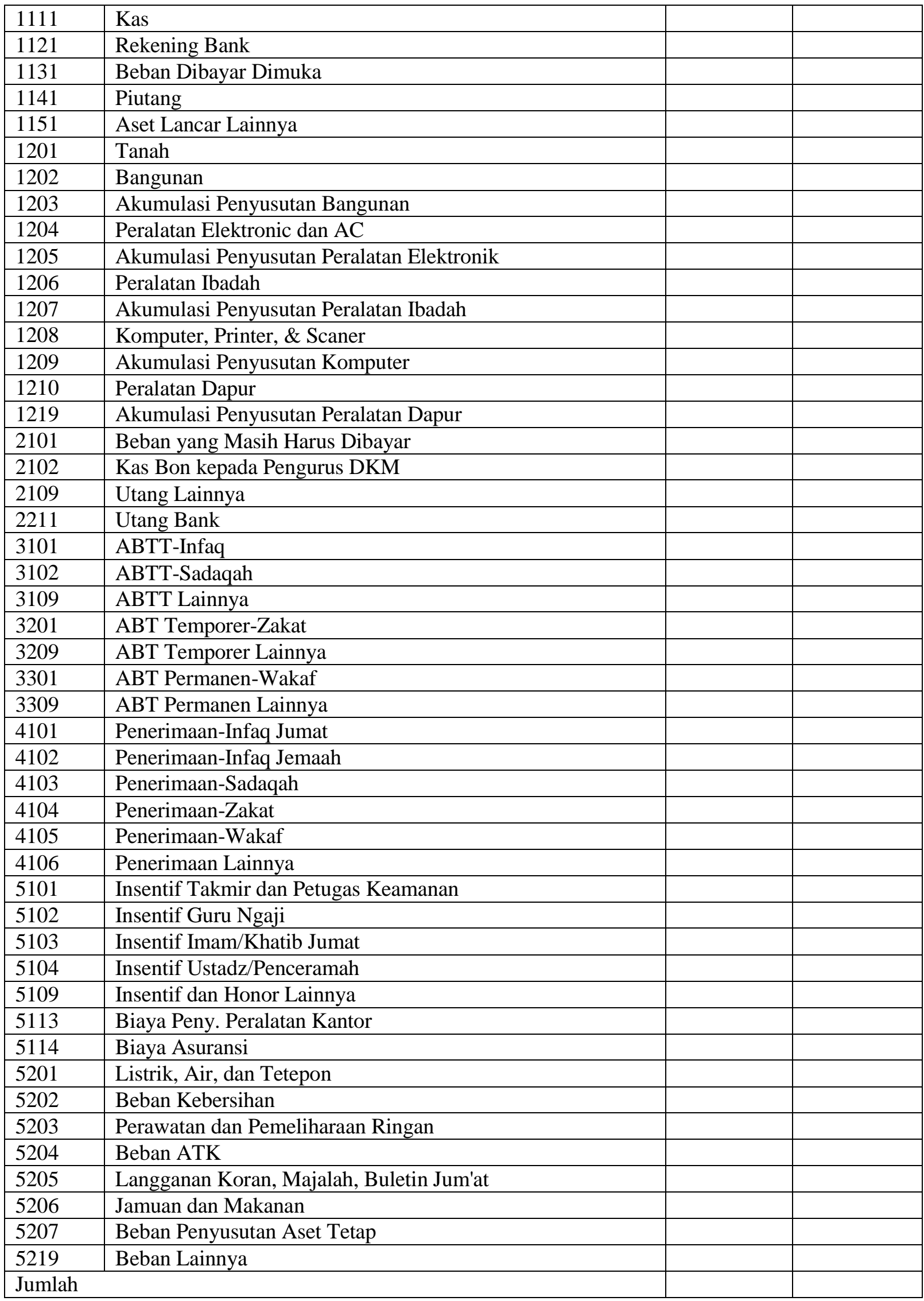

\section{b. Format Jurnal Khusus Tanggal 01 Januari 20XX sampai 31 Desember 20XX}

1) Jurnal Khusus Penerimaan Kas

Berikut format Jurnal Khusus Penerimaan Kas 01 Januari 20XX sampai 31 Desember 20XX pada Masjid. 
Tabel 4.Jurnal Khusus Penerimaan Kas Masjid XXX

Jurnal Khusus Penerimaan Kas

Per 01 Januari s/d 31 Desember 20XX

Dalam Rupiah (Rp)

\begin{tabular}{|c|c|c|c|c|c|c|c|c|c|}
\hline \multirow[t]{3}{*}{$\mathrm{Tgl}$} & \multirow{3}{*}{ Ket } & \multicolumn{8}{|c|}{ Kredit } \\
\hline & & \multicolumn{4}{|c|}{ Penerimaan Tidak Terikat } & \multicolumn{2}{|c|}{$\begin{array}{ll}\text { Penerimaan } & \text { Terikat } \\
\text { Temporer } & \end{array}$} & \multicolumn{2}{|c|}{$\begin{array}{r}\text { Penerimaan } \\
\text { Terikat Permanen }\end{array}$} \\
\hline & & Kas & $\begin{array}{l}\text { ABTT- } \\
\text { Infaq }\end{array}$ & $\begin{array}{l}\text { ABTT- } \\
\text { Sadaqah }\end{array}$ & $\begin{array}{l}\text { ABTT } \\
\text { Lainnya }\end{array}$ & $\begin{array}{l}\text { ABT } \\
\text { Temporer- } \\
\text { Zakat }\end{array}$ & $\begin{array}{l}\text { ABT } \\
\text { Temporer } \\
\text { Lainnya }\end{array}$ & $\begin{array}{l}\text { ABT } \\
\text { Permanen- } \\
\text { Wakaf }\end{array}$ & $\begin{array}{l}\mathrm{ABT} \\
\text { Permanen } \\
\text { Lainnya }\end{array}$ \\
\hline & & 1111 & 3101 & 3102 & 3109 & 3201 & 3209 & $\begin{array}{ll} & 330 \\
1 & \end{array}$ & $9 \quad 330$ \\
\hline & & & & & & & & & \\
\hline & & & & & & & & & \\
\hline & & & & & & & & & \\
\hline & & & & & & & & & \\
\hline
\end{tabular}

2) Rekapitulasi Jurnal Khusus Penerimaan Kas

Berikut Format Rekapitulasi Jurnal Khusus Penerimaan Kas 31 Desember 20XX pada Masjid :

Tabel 5. Rekapitulasi Jurnal Khusus Penerimaan Kas Masjid XXX

Rekapitulasi Jurnal Khusus Penerimaan Kas

Per 01 Januari s/d 31 Desember 20XX Dalam Rupiah (Rp)

\begin{tabular}{|c|l|l|l|}
\hline Kode Akun & Keterangan & Debit & Kredit \\
\hline 1111 & Kas & & \\
\hline 3101 & ABTT-Infaq & & \\
\hline 3102 & ABTT-Sadaqah & & \\
\hline 3103 & ABTT Lainnya & & \\
\hline 3201 & ABT Temporer-Zakat & \\
\hline 3209 & ABT Temporer Lainnya & & \\
\hline 3301 & ABT Permanen-Wakaf & & \\
\hline 3302 & ABT Permanen Lainnya & & \\
\hline Jumlah & & & \\
\hline
\end{tabular}

3) Jurnal Khusus Pengeluaran Kas

Berikut Format Jurnal Khusus Pengeluaran Kas 01 Januari 20XX sampai 31 Desember 20XX pada Masjid :

Tabel 6. Jurnal Khusus Pengeluaran Kas Masjid XXX

Jurnal Khusus Pengeluaran Kas

Per 01 Januari s/d 31 Desember 20XX

Dalam Rupiah (Rp)

\begin{tabular}{|c|c|c|c|c|c|c|c|c|c|c|c|c|}
\hline Tgl & Ket & Debit & & & & & & & & & & Kredit \\
\hline & & $\begin{array}{l}\text { Insenti } \\
\mathrm{f}\end{array}$ & $\begin{array}{l}\text { Ust/ } \\
\text { Penceram } \\
\text { ah }\end{array}$ & $\begin{array}{l}\text { Peny. } \\
\text { Peralata } \\
\mathrm{n} \\
\text { Kantor }\end{array}$ & $\begin{array}{l}\text { Biaya } \\
\text { Asurans } \\
\text { i }\end{array}$ & $\begin{array}{l}\text { Listrik } \\
\text { Air, } \\
\text { dan } \\
\text { Telepo } \\
\text { n }\end{array}$ & $\begin{array}{l}\text { Pem } \\
\text { ruan } \\
\mathrm{g}\end{array}$ & $\begin{array}{l}\text { Beba } \\
\text { n } \\
\text { ATK }\end{array}$ & $\begin{array}{l}\text { Langg } \\
\text { anan } \\
\text { Koran, } \\
\text { Majala } \\
\text { hBulet } \\
\text { in } \\
\text { Jum'at }\end{array}$ & $\begin{array}{l}\text { Beba } \\
\mathrm{n} \\
\text { Peny. } \\
\text { Aset } \\
\text { Tetap }\end{array}$ & $\begin{array}{l}\text { Beban } \\
\text { Lain }\end{array}$ & Kas \\
\hline & & 5103 & 5104 & 5113 & 5114 & 5201 & $\begin{array}{l}520 \\
3\end{array}$ & 5204 & 5205 & 5207 & 5219 & 1111 \\
\hline & & & & & & & & & & & & \\
\hline
\end{tabular}

4) Rekapitulasi Jurnal Khusus Pengeluaran Kas 
Berikut Format Rekapitulasi Jurnal Khusus Pengeluaran Kas 31 Desember 20XX pada Masjid :

Tabel 7. Rekapitulasi Jurnal Khusus Pengeluaran Kas

Masjid XXX

Rekapitulasi Jurnal Khusus Pengeluaran Kas

Per 31 Desember 20XX

Dalam Rupiah (Rp)

\begin{tabular}{|c|l|l|l|}
\hline Kode Akun & \multicolumn{1}{|c|}{ Keterangan } & Debet & Kredit \\
\hline 1111 & Kas & & \\
\hline 5103 & Insentif Imam/Khatib Jumat & & \\
\hline 5104 & Insentif Ustadz/Penceramah & & \\
\hline 5113 & Biaya Peny. Peralatan Kantor & & \\
\hline 5114 & Biaya Asuransi & & \\
\hline 5201 & Listrik, Air, dan Tetepon & & \\
\hline 5203 & Pemeliharaan Ruang & & \\
\hline 5204 & Beban ATK & & \\
\hline 5205 & $\begin{array}{l}\text { Langganan Koran, Majalah, Buletin } \\
\text { Jum'at }\end{array}$ & & \\
\hline 5207 & Beban Penyusutan Aset Tetap & & \\
\hline 5219 & Beban Lainnya & & \\
\hline Jumlah & & & \\
\hline
\end{tabular}

c. Format jurnal penyesuaian periode 31 Desember 20XX pada Masjid

Berikut Format jurnal penyesuaian 31 Desember 20XX pada Masjid :

Tabel 8. Jurnal Penyesuaian

Masjid XXX

Jurnal Penyesuaian

Per 31 Desember 20XX

Dalam Rupiah (Rp)

\begin{tabular}{|l|l|l|c|c|}
\hline Tgl & $\begin{array}{l}\text { Kode } \\
\text { Akun }\end{array}$ & Keterangan & Debet & Kredit \\
\hline & 5207 & Beban Penyusutan Aset Tetap & - & - \\
\hline & 1203 & Akumulasi Penyusutan Bangunan & & - \\
\hline & 5207 & Beban Penyusutan Aset Tetap & - & - \\
\hline & 1205 & $\begin{array}{l}\text { Akumulasi Penyusutan Peralatan } \\
\text { Elektronik }\end{array}$ & & - \\
\hline & 5207 & Beban Penyusutan Aset Tetap & - & - \\
\hline & 1207 & $\begin{array}{l}\text { Akumulasi Penyusutan Peralatan } \\
\text { Ibadah }\end{array}$ & & \\
\hline & 5207 & Beban Penyusutan Aset Tetap & - & \\
\hline & 1209 & Akumulasi Penyusutan Komputer & & \\
\hline
\end{tabular}




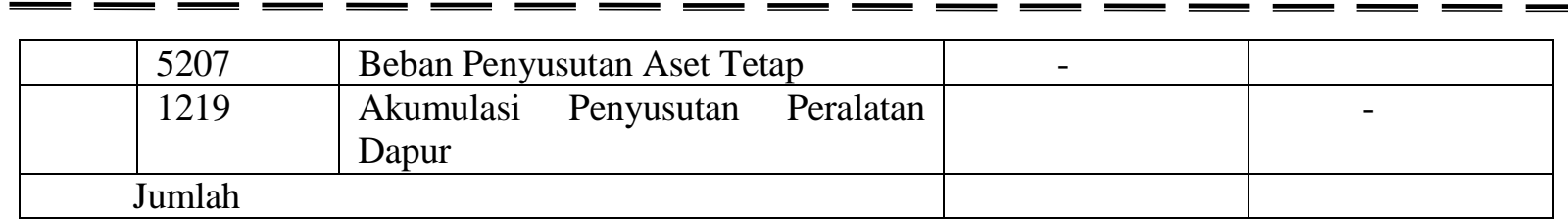

d. Format Jurnal Khusus dan Jurnal Penyesuaian ke buku besar periode 31 Desember 20XX pada Masjid

Berikut Format Tabel Posting Jurnal Khusus dan jurnal penyesuaian ke buku besar periode 31

Desember 20XX :

Tabel 9. Buku Besar

Masjid XXX

Buku Besar

Per 31 Desember 20XX

Dalam Rupiah (Rp)

Nama akun :.........

\begin{tabular}{|c|l|l|l|c|c|c|}
\hline Tanggal & Keterangan & Ref & Debit & Kredit & \multicolumn{2}{|c|}{ Saldo } \\
\cline { 5 - 7 } & & & & & Debit & Kredit \\
\hline- & Saldo awal & & & & - & \\
\hline- & $\begin{array}{l}\text { Jurnal } \\
\text { Penerimaan } \\
\text { Kas }\end{array}$ & & - & & - & \\
\hline- & $\begin{array}{l}\text { Khusus } \\
\text { pengeluaran } \\
\text { kas }\end{array}$ & & & - & - & \\
\hline
\end{tabular}

e. Format neraca saldo setelah penyesuaian periode 31 Desember 20XX pada Masjid Berikut Format tabel Neraca Saldo Setelah Penyesuaian 31 Desember 20XX pada Masjid :

Tabel 10. Neraca Saldo Setelah Penyesuaian

$$
\text { Masjid XXX }
$$

Neraca Saldo Setelah Penyesuaian

Per Desember 20XX

Dalam Rupiah (Rp)

\begin{tabular}{|l|l|l|l|}
\hline \multirow{2}{*}{ Kode akun } & \multicolumn{1}{|c|}{ Nama akun } & Saldo & Debit \\
\cline { 3 - 4 } & & & \\
\hline 1111 & Kas & & \\
\hline 1121 & Rekening Bank & & \\
\hline 1131 & & & \\
\hline 1141 & Beban Dibayar Dimuka & & \\
\hline 1151 & Piutang & Aset Lancar Lainnya & \\
\hline 1201 & Tanah & & \\
\hline 1202 & Bangunan & & \\
\hline 1203 & Akumulasi Penyusutan Bangunan & & \\
\hline 1204 & Peralatan Elektronic dan AC & & \\
\hline 1205 & $\begin{array}{l}\text { Akumulasi Penyusutan Peralatan } \\
\text { Elektronik }\end{array}$ & & \\
\hline 1206 & Peralatan Ibadah & & \\
\hline
\end{tabular}


ProBank : Jurnal Ekonomi Dan Perbankan

ISSN : 2579-5597 (online)

Vol 1, No 1 (2021) ; p.14-33;-http://e-journal.stie-aub.ac.id/index.php/probank

ISSN : 2252-7885 (cetak)

\begin{tabular}{|c|c|c|c|}
\hline 1207 & $\begin{array}{l}\text { Akumulasi Penyusutan Peralatan } \\
\text { Ibadah }\end{array}$ & & \\
\hline 1208 & Komputer, Printer, \& Scaner & & \\
\hline 1209 & Akumulasi Penyusutan Komputer & & \\
\hline 1210 & Peralatan Dapur & & \\
\hline 1219 & $\begin{array}{l}\text { Akumulasi Penyusutan Peralatan } \\
\text { Dapur }\end{array}$ & & \\
\hline 2101 & $\begin{array}{llll}\text { Beban yang } & \text { Masih } & \text { Harus } \\
\text { Dibayar }\end{array}$ & & \\
\hline 2102 & Kas Bon kepada Pengurus DKM & & \\
\hline 2109 & Utang Lainnya & & \\
\hline 2211 & Utang Bank & & \\
\hline 3101 & ABTT-Infaq & & \\
\hline 3102 & ABTT-Sadaqah & & \\
\hline 3109 & ABTT Lainnya & & \\
\hline 3201 & ABT Temporer-Zakat & & \\
\hline 3209 & ABT Temporer Lainnya & & \\
\hline 3301 & ABT Permanen-Wakaf & & \\
\hline 3309 & ABT Permanen Lainnya & & \\
\hline 4101 & Penerimaan-Infaq Jumat & & \\
\hline 4102 & Penerimaan-Infaq Jemaah & & \\
\hline 4103 & Penerimaan-Sadaqah & & \\
\hline 4104 & Penerimaan-Zakat & & \\
\hline 4105 & Penerimaan-Wakaf & & \\
\hline 4106 & Penerimaan Lainnya & & \\
\hline 5101 & $\begin{array}{l}\text { Insentif Takmir dan Petugas } \\
\text { Keamanan }\end{array}$ & & \\
\hline 5102 & Insentif Guru Ngaji & & \\
\hline 5103 & Insentif Imam/Khatib Jumat & & \\
\hline 5104 & Insentif Ustadz/Penceramah & & \\
\hline 5109 & Insentif dan Honor Lainnya & & \\
\hline 5113 & Biaya Peny. Peralatan Kantor & & \\
\hline 5114 & Biaya Asuransi & & \\
\hline 5201 & Listrik, Air, dan Tetepon & & \\
\hline 5202 & Beban Kebersihan & & \\
\hline 5203 & $\begin{array}{l}\text { Perawatan dan Pemeliharaan } \\
\text { Ringan }\end{array}$ & & \\
\hline 5204 & Beban ATK & & \\
\hline 5205 & $\begin{array}{l}\text { Langganan Koran, Majalah, } \\
\text { Buletin Jum'at }\end{array}$ & & \\
\hline 5206 & Jamuan dan Makanan & & \\
\hline 5207 & Beban Penyusutan Aset Tetap & & \\
\hline 5219 & Beban Lainnya & & \\
\hline \multicolumn{2}{|c|}{ Jumlah } & & \\
\hline
\end{tabular}

f. Format jurnal penutup setelah penyesuaian periode 31 Desember 20XX pada Masjid

Berikut Format Tabel Jurnal Penutup Setelah Penyesuaian periode 31 Desember 20XX pada Masjid

Tabel 11. Jurnal Penutup

Masjid XXX

Jurnal Penutup 
Per Desember 20XX

Dalam Rupiah (Rp)

\begin{tabular}{|l|l|l|l|}
\hline \multirow{2}{*}{$\begin{array}{l}\text { Kode } \\
\text { akun }\end{array}$} & \multicolumn{1}{|c|}{ Nama akun } & \multicolumn{2}{c|}{ Saldo } \\
\cline { 3 - 4 } & & Debit & \\
\hline 4101 & Penerimaan-Infaq Jumat & \\
\hline 4102 & Penerimaan-Infaq Jemaah & & \\
\hline 4103 & Penerimaan-Sadaqah & & \\
\hline 4104 & Penerimaan-Zakat & & \\
\hline 4105 & Penerimaan-Wakaf & \\
\hline 4106 & Penerimaan Lainnya & \\
\hline 5101 & $\begin{array}{l}\text { Insentif Takmir dan Petugas } \\
\text { Keamanan }\end{array}$ & & \\
\hline 5102 & Insentif Guru Ngaji & & \\
\hline 5103 & Insentif Imam/Khatib Jumat & \\
\hline 5104 & Insentif Ustadz/Penceramah & & \\
\hline 5109 & Insentif dan Honor Lainnya & & \\
\hline 5113 & Biaya Peny. Peralatan Kantor & & \\
\hline 5114 & Biaya Asuransi & & \\
\hline 5201 & Listrik, Air, dan Tetepon & \\
\hline 5202 & Beban Kebersihan & & \\
\hline 5203 & Perawatan dan Pemeliharaan Ringan & & \\
\hline 5204 & Beban ATK & & \\
\hline 5205 & $\begin{array}{l}\text { Langganan Koran, Majalah, Buletin } \\
\text { Jum'at }\end{array}$ & & \\
\hline 5206 & Jamuan dan Makanan & & \\
\hline 5207 & Beban Penyusutan Aset Tetap & & \\
\hline 5219 & Beban Lainnya & & \\
\hline & Jumlah & & \\
\hline & & & \\
\hline
\end{tabular}

Masjid

g. Format jurnal penutup ke buku besar setelah penutupan per 31 Desember 20XX pada

Berikut Format Buku Besar Setelah Penutupan periode 31 Desember 20XX pada Masjid :

Tabel 12. Buku Besar Setelah Penutupan

$$
\text { Masjid XXX }
$$

Buku Besar Setelah Penutupan

Per 31 Desember 20XX

Dalam Rupiah (Rp)

Nama akun

kode akun : ........

\begin{tabular}{|c|l|l|l|l|c|c|}
\hline & & & & \multicolumn{2}{|c|}{ Saldo } \\
\hline Tanggal & Keterangan & Ref & Debit & Kredit & Debit & Kredit \\
\hline- & Saldo awal & & & & - & \\
\hline- & $\begin{array}{l}\text { Jurnal } \\
\text { Penerimaan } \\
\text { Kas }\end{array}$ & & - & & - & \\
\hline- & $\begin{array}{l}\text { Khusus } \\
\text { pengeluaran } \\
\text { kas }\end{array}$ & & & - & - & \\
\hline
\end{tabular}

Untuk akun pendapatan format tabelnya adalah sebagai berikut :

Nama akun :Penerimaan infaq Jumat

kode akun : 4101

\begin{tabular}{|l|l|l|l|l|l|l|}
\hline & & & & \multicolumn{2}{c|}{ Saldo } \\
\hline Tanggal & Keterangan & Ref & Debit & Kredit & Debit & Kredit \\
\hline
\end{tabular}




\begin{tabular}{|c|l|l|c|c|c|c|}
\hline- & Saldo awal & & & & & \\
\hline- & $\begin{array}{l}\text { Jurnal } \\
\text { Penerimaan } \\
\text { Kas }\end{array}$ & & & - & & - \\
\hline- & $\begin{array}{l}\text { Jurnal } \\
\text { Penutup }\end{array}$ & & - & & & - \\
\hline
\end{tabular}

Untuk akun beban format tabelnya adalah sebagai berikut :

Nama akun : Beban Kebersihan
\begin{tabular}{|c|l|l|l|l|l|c|}
\hline & & & & \multicolumn{2}{c|}{ Saldo } \\
\hline Tanggal & Keterangan & Ref & Debit & Kredit & Debit & Kredit \\
\hline- & Saldo awal & & & & & - \\
\hline- & $\begin{array}{l}\text { Jurnal } \\
\text { Pengeluaran } \\
\text { kas }\end{array}$ & & & - & & - \\
\hline- & $\begin{array}{l}\text { Jurnal } \\
\text { Penutup }\end{array}$ & & - & & & \\
\hline
\end{tabular}

\section{h. Format neraca saldo akhir per 31 Desember 2016 pada Masjid}

Berikut Format Tabel Neraca Saldo Akhir periode 31 Desember 20XX pada Masjid:

Tabel 13.

Neraca Saldo Tahun Sebelumnya

Per 31 Desember 20XX

Dalam Rupiah (Rp)

\begin{tabular}{|l|l|l|l|}
\hline \multirow{2}{*}{$\begin{array}{l}\text { Kode } \\
\text { akun }\end{array}$} & Nama akun & Saldo & \\
\hline 1111 & Kas & Debit & Kredit \\
\hline 1121 & Rekening Bank & & \\
\hline 1131 & Beban Dibayar Dimuka & & \\
\hline 1141 & Piutang & & \\
\hline 1151 & Aset Lancar Lainnya & & \\
\hline 1201 & Tanah & & \\
\hline 1202 & Bangunan & & \\
\hline 1203 & Akumulasi Penyusutan Bangunan & & \\
\hline 1204 & Peralatan Elektronic dan AC & & \\
\hline 1205 & Akumulasi Penyusutan Peralatan Elektronik & & \\
\hline 1206 & Peralatan Ibadah & & \\
\hline 1207 & Akumulasi Penyusutan Peralatan Ibadah & & \\
\hline 1208 & Komputer, Printer, \& Scaner & & \\
\hline 1209 & Akumulasi Penyusutan Komputer & & \\
\hline 1210 & Peralatan Dapur & & \\
\hline 1219 & Akumulasi Penyusutan Peralatan Dapur & & \\
\hline 2101 & Beban yang Masih Harus Dibayar & & \\
\hline 2102 & Kas Bon kepada Pengurus DKM & & \\
\hline 2109 & Utang Lainnya & & \\
\hline 2211 & Utang Bank & & \\
\hline 3101 & ABTT-Infaq & & \\
\hline 3102 & ABTT-Sadaqah & & \\
\hline 3109 & ABTT Lainnya & & \\
\hline 3201 & ABT Temporer-Zakat & & \\
\hline
\end{tabular}




\begin{tabular}{|l|l|l|l|}
\hline 3209 & ABT Temporer Lainnya & & \\
\hline 3301 & ABT Permanen-Wakaf & & \\
\hline 3309 & ABT Permanen Lainnya & & \\
\hline 4101 & Penerimaan-Infaq Jumat & & \\
\hline 4102 & Penerimaan-Infaq Jemaah & & \\
\hline 4103 & Penerimaan-Sadaqah & & \\
\hline 4104 & Penerimaan-Zakat & & \\
\hline 4105 & Penerimaan-Wakaf & & \\
\hline 4106 & Penerimaan Lainnya & & \\
\hline 5101 & Insentif Takmir dan Petugas Keamanan & & \\
\hline 5102 & Insentif Guru Ngaji & & \\
\hline 5103 & Insentif Imam/Khatib Jumat & & \\
\hline 5104 & Insentif Ustadz/Penceramah & & \\
\hline 5109 & Insentif dan Honor Lainnya & & \\
\hline 5113 & Biaya Peny. Peralatan Kantor & & \\
\hline 5114 & Biaya Asuransi & & \\
\hline 5201 & Listrik, Air, dan Tetepon & & \\
\hline 5202 & Beban Kebersihan & & \\
\hline 5203 & Perawatan dan Pemeliharaan Ringan & & \\
\hline 5204 & Beban ATK & & \\
\hline 5205 & Langganan Koran, Majalah, Buletin Jum'at & & \\
\hline 5206 & Jamuan dan Makanan & & \\
\hline 5207 & Beban Penyusutan Aset Tetap & & \\
\hline 5219 & Beban Lainnya & & \\
\hline Jumlah & & & \\
\hline
\end{tabular}

\section{i. $\quad$ Format laporan keuangan Masjid sesuai PSAK No.45}

Laporan Keuangan tentunya sangat bermanfaat bagi Masjid. Laporan keuangan ini digunakan untuk mengambil keputusan penting dan juga sebagai pertanggungjawaban masjid terhadap dana yang dikelolanya.

Tujuan dari laporan posisi keuangan adalah untuk memberikan informasi mengenai aset, liabilitas, dan aset neto yang ada di masjid tersebut. Berikut format laporan keuangan Masjidn: 
ProBank : Jurnal Ekonomi Dan Perbankan

ISSN : 2579-5597 (online)

Vol 1, No 1 (2021) ; p.14-33;-http://e-journal.stie-aub.ac.id/index.php/probank ISSN : 2252-7885 (cetak)

MASJID XXX

Laporan Posisi Keuangan

tanggal 31-12-20XX

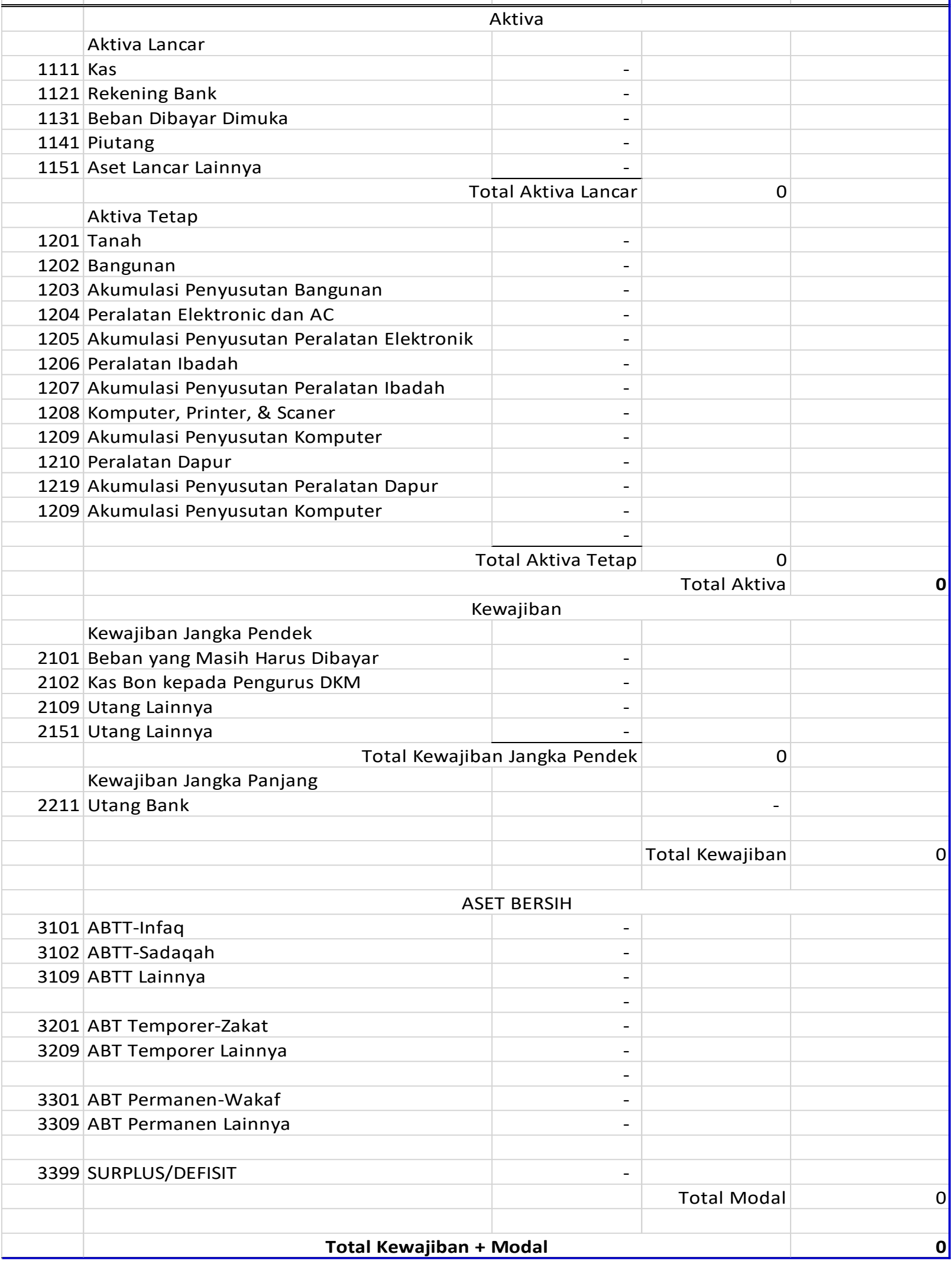

Laporan aktivitas memberikan informasi mengenai kinerja keuangan masjid dalam satu periode tertentu yang menyajikan informasi mengenai pengaruh transaksi dan peristiwa lain yang merubah aset neto. 
Berikut merupakan rekomendasi format laporan aktivitas masjid:

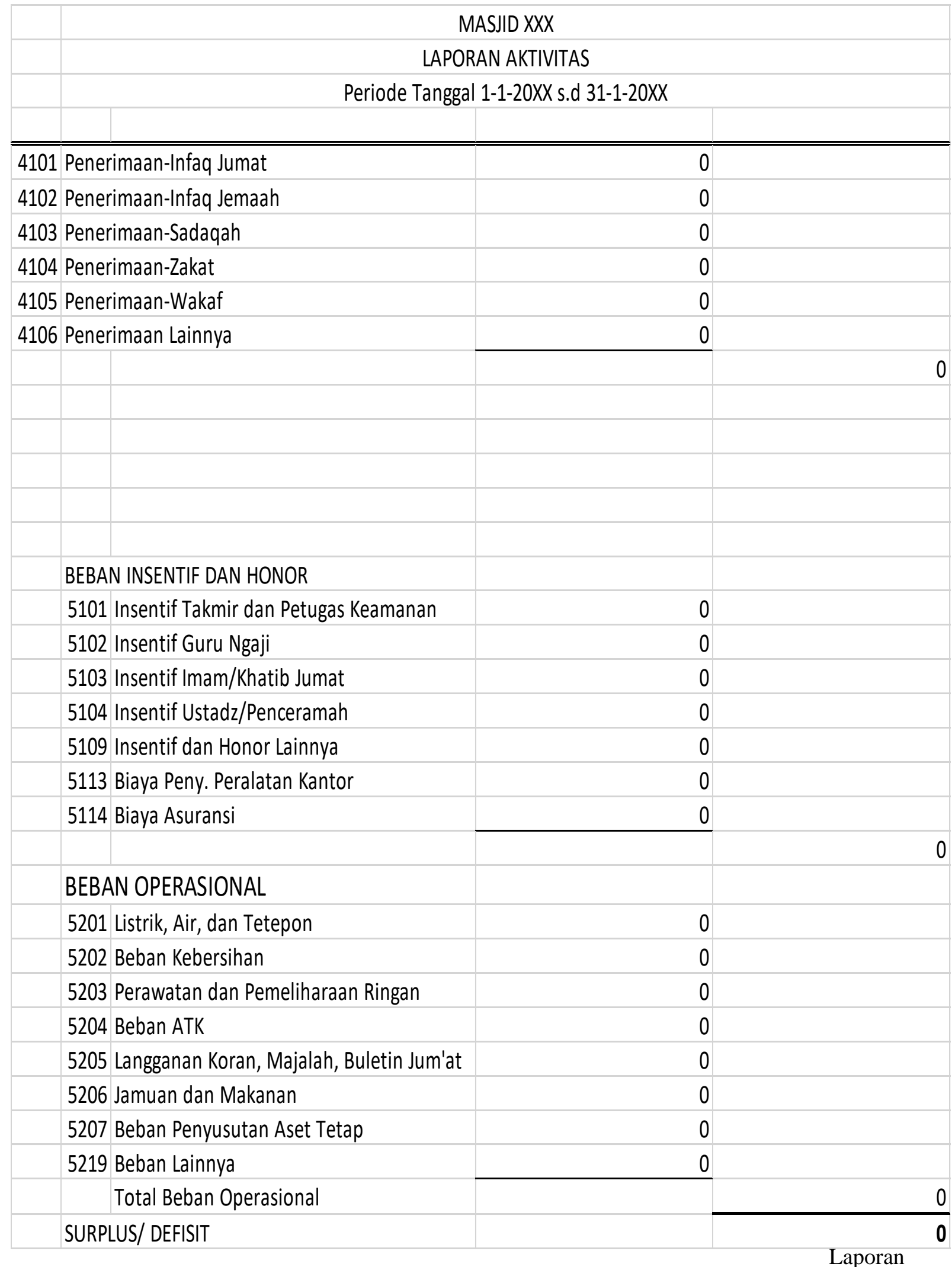

arus kas adalah laporan yang menunjukan penerimaan dan pengeluaran kas dalam periode tertentu yang dikelompokan menjadi aktivitas operasional, investasi, dan juga pendanaan. 


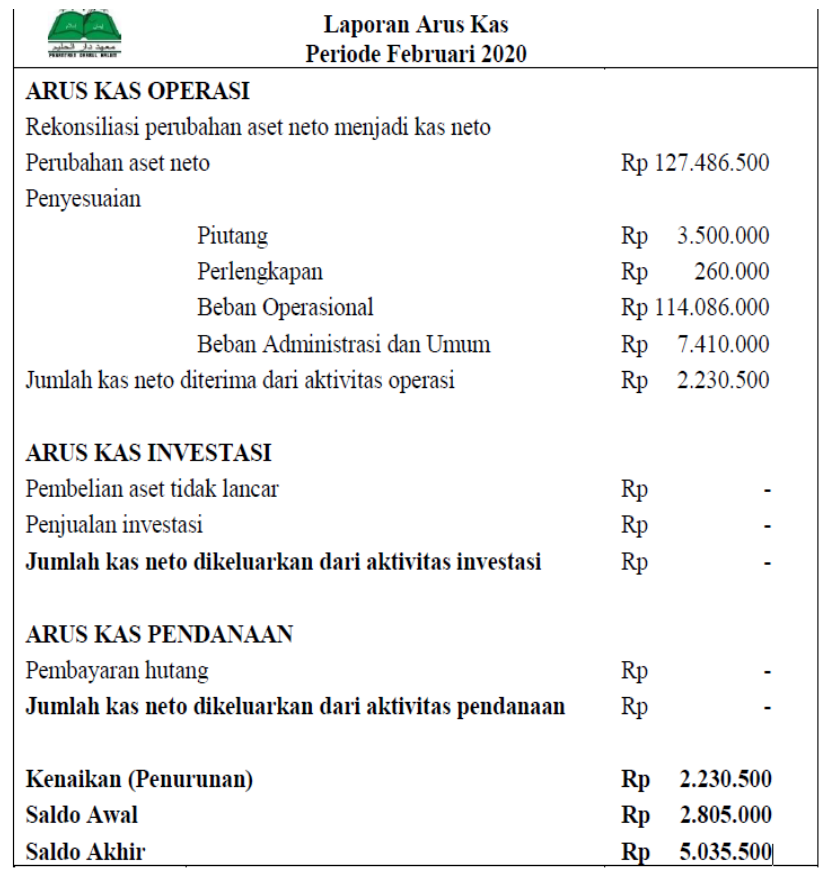

Catatan atas laporan keuangan merupakan pelengkap laporan keuangan yang memuat penjelasan mengenai pos-pos laporan keuangan dan informasi penting lainnya.

\section{PENUTUP}

\section{Simpulan}

Berdasarkan hasil penelitian dan pembahasan tentang penyusunan sistem akuntansi pokok berdasarkan PSAK 45 pada Masjid Lukmanul Hakim dan DKM At-Taqwa, dapat diambil kesimpulan sebagai berikut:

1. Pencatatan keuangan yang dilakukan oleh Masjid Lukmanul Hakim dan DKM At-Taqwa adalah pencatatan yang sederhana karena hanya mencatat penerimaan dan pengeluaran kas secara single entry. Pencatatan ini dilakukan oleh bagian bendahara yang kemudian tiap minggunya diumumkan dan setiap bulan dilaporkan kepada pimpinan Masjid Lukmanul Hakim dan DKM At-Taqwa.

2. Masjid Lukmanul Hakim dan DKM At-Taqwa belum menyajikan laporan keuangan yang sesuai dengan PSAK 45. Dalam PSAK 45 dijelaskan bahwa laporan keuangan masjid yang lengkap terdiri dari laporan posisi keuangan, laporan aktivitas, laporan arus kas, dan catatan atas laporan keuangan.

3. Penerapan sistem akuntansi pokok berdasarkan PSAK 45 sangat memungkinkan jika diterapkan secara penuh pada Masjid Lukmanul Hakim dan DKM At-Taqwa.

4. Penerapan sistem akuntansi pokok berdasarkan PSAK 45 bermanfaat bagi Masjid Lukmanul Hakim dan DKM At-Taqwa dalam pengambilan keputusan dan sebagai bentuk pertanggungjawaban pengelolaan keuangan masjid.

\section{Saran}

Berdasarkan hasil analisa dan kesimpulan, maka penulis memberikan saran sebagai berikut:

1. Masjid Lukmanul Hakim dan DKM At-Taqwa diharapkan tidak hanya mencatat penerimaan dan pengeluaran kasnya saja. Akan tetapi juga melakukan pencatatan hutang, piutang, dan melakukan pendataan inventaris secara rutin.

2. Perlu adanya sosialisasi dan pelatihan mengenai Pedoman Akuntansi Masjid agar Bendahara lebih memahami dan bisa menerapkannya.

3. Bagian keuangan dan bendahara diharapkan bisa memahami dan mempelajari sistem akuntansi pokok dan juga Pedoman Akuntansi Masjid.

4. Bagi peneliti selanjutnya diharapkan dapat memperbaiki kekurangan dan kelemahan yang ada pada penelitian ini sehingga penelitian selanjutnya dapat lebih baik. Diharapkan juga penelitian 
selanjutnya menemukan objek yang lebih kompleks, seperti masjid yang sudah memiliki berbagai macam kegiatan usaha.

\section{UCAPAN TERIMAKASIH}

Ucapan terimakasih disampaikan kepada semua pihak yang telah berperan dalam penyelesaian penelitian ini sehingga dapat dituangkan dalam bentuk tulisan. Kemudian terima kasih yang sebesarbesarnya diucapkan kepada Politeknik Negeri Bandung yang telah memberikan bantuan dana dari sumber DIPA POLBAN untuk penelitian ini.

\section{DAFTAR PUSTAKA}

[1] Afifuddin, Hasan Basri and Siti-Nabiha, A.K, 2010, "Towards Good Accountability: The Role of Accounting in Islamic Religious Organisations", World Academy of Science, Engineering and Technology International Journal of Social, Behavioral, Educational, Economic, Business and Industrial Engineering Vol:4, No:6, 2010

[2] Andikawati, Desi dan Wahyu Agus Winarno. 2014. Financial Report of The Mosque Institute (The Case Study At Anaz Mahfudz and Al - Huda Mosque). Artikel Ilmiah Mahasiswa. 1-6.

[3] Gelinas, Jr., Ulric.J. , Dull, Richard B., 2008, Accounting Information Systems, 7th edition, Thomson South-Western, USA

[4] Gillespie, Cecil, 1981, Accounting Systems: Procedurs and Methods, Prentice Hall of India, New Delhi

[5] Hall, James A., 2011, Accounting Information Systems, seventh edition, South Western Cengage Learning,

[6] Mardiasmo, 2005, Akuntansi Sektor Publik, Penerbit Andi Yogyakarta

[7] Meleong, Lexy J, 2017, Metodologi Penelitian Kualitatif, Penerbit Remaja Rosdakarya, Bandung,

[8] Mulyadi, 2014, Sistem Akuntansi, Edisi ke-4, Penerbit Salemba Empat, Jakarta

[9] Nariasih, Dewi Yibta, Taufik Kurrohman, Andriana, 2017 "Laporan Keuangan Masjid Berdasarkan Kombinasi PSAK Nomor 45 dan PSAK Nomor 109 (Studi Kasus Pada Masjid XYZ)"; e-Journal Ekonomi Bisnis dan Akuntansi, 2017, Volume IV (1) : 6-11

[10] Novitasari, Christin Dwi, Yulinartati, Dania Puspitasari, 2018, "Penerapan PSAK No.45 pada Laporan Keuangan Lembaga Masjid", International Journal of Social Science and Business. Volume 2, Number 4, Tahun 2018, pp. 197-202 P-ISSN : 2614-6533 E-ISSN : 2549-640

[11] Pinson, Linda, 2007, Keeping The Books: Basic Recordkeeping and Accounting for the Successful Small Business, Seventh Edition (2007), Kaplan Publishing, Chicago

[12] Romney, Marshal B., Steinbart, Paul J., 2018, Accounting Information Systems, Pearson Education, Inc., Fourteenth Edition., New York, USA

[13] Satori, Djam'an, Aan Komariah, 2014, Metodologi Penelitian Kualitatif, Penerbit Alfabeta, Bandung,

[14] Sugiyono, 2015, Memahami Penelitian Kualitatif, Penerbit Alfabeta, Bandung,

[15] Taylor, Peter, 2008, Book-Keeping \& Accounting for Small Business, 7th edition (2008), Published by How To Books Ltd, Oxford 0X5 1RX. United Kingdom. 